\title{
Wild type Bacillus subtilis treated with ethyl methyl sulphonate produced catabolite insensitive mutants with improved cellulase production
}

Oladipo Olaniyi ( $\nabla$ microladit@gmail.com )

Federal University of Technology

Original article

Keywords: Cellulases, mutagenesis, carboxylmethylcellulose, catabolite repression, glucose

Posted Date: March 11th, 2021

DOl: https://doi.org/10.21203/rs.3.rs-278081/v1

License: (1) (1) This work is licensed under a Creative Commons Attribution 4.0 International License.

Read Full License 


\section{Abstract}

The goal of this present investigation was to mutagenize Bacillus subtilis with Ethyl Methyl Sulphonate (EMS), screen the mutants for cellulase production and evaluate the influence of different glucose concentrations on their cellulase production potentials. The wild type $B$. subtilis was treated with 20,40 , 60 and $80 \mu \mathrm{l}$ of EMS and the mutants generated were screened for cellulase production in minimal salt medium containing carboxylmethylcellulose (CMC) as the carbon source. Quantitatively, cellulase activity and protein contents were determined by dinitrosalicylic acid and Lowry methods respectively. Seven mutants were developed from each of the EMS concentration bringing the total to twenty-eight from all the concentrations. Approximately 14 and $57 \%$ of the mutants developed from 40 and $60 \mu \mathrm{l}$ of EMS had higher cellulase activities than the wild type, while none of the mutants developed from 20 and $80 \mu \mathrm{l}$ of EMS had better activities than the wild type. The supplementation of $0.2,0.5,1.0$ and $1.5 \%$ glucose in enzyme production medium caused approximately 100,14, 29 and $14 \%$ cellulase repression respectively in the mutants developed from $60 \mu$ I EMS. Mutants MSSS02 and MSSS05 were considered as catabolite insensitive mutants because their cellulase production were enhanced in comparison to wild type.

\section{Introduction}

In the last few decades of studying bioconversion of cellulose from lignocellulosic biomass, it has been affirmed that it is pivotal to the production of fermentation sugars, a template molecule for the synthesis of Adenosine Triphosphate (ATP), a renewable energy source in the biosphere (Romeo, 2008; Islam and Roy, 2018). Cellulose is a homopolymer of repeated units of $D$-glucose linked by $\beta-1,4$ glyosidic bonds. It is one of the major structural components of plant biomass in nature and most abundant biomass generated via various agricultural practices (Islam and Roy, 2018). Usually, a complete degradation of cellulose into glucose units is achieved by synergistic interaction of three types of cellulases namely: $\beta-1,4$ endoglucanases, cellobiohydrolase and $\beta$-D glucosidase (Perez et al., 2002; Bras et al., 2011). $\beta-1,4$ endoglucanases targets and hydrolyze exposed glyosidic bonds within the cellulose polymer, cellobiohydrolase liberates cellobiose from the reducing and nonreducing ends, while $\beta$-D glucosidase cleaves cellobiose and cello-oligosaccharide into glucose (Bras et al., 2011; Shanmugapriya et al., 2012). It is therefore imperative to develop research strategies for an effective utilization of cellulose containing wastes as cheap carbon sources.

Recently, microbial cellulases have attracted much attention because of exponential increase in the application of these enzymes in detergent, textile, food, leather, paper and feed industries. It has also found application in fiber modification, biomass fermentation and pharmaceutical purposes (Cherry and Fidantsef, 2003; Shanmugapriya et al., 2012). Industrial application of cellulases requires proper identification of promising microbial candidates with good cellulolytic machinery that are stable at extreme conditions such as high temperature and pH (Abdelnasser and Ahmed, 2007). Numerous cellulose-degrading microorganisms have isolated and identified with many studies laid more emphasis on cellulases from fungal origin due to the fact that they produced it in abundant, easier to extract from production medium and it has been commercialized (Saha et al., 2006; Doi, 2008). However, researchers 
are now considering cellulase-producing bacteria because their growth rate is faster than fungi, they express multienzyme complexes and are resistant to extreme environmental stress (Waeonukul et al., 2009; Deswal et al., 2011; Marjamaa et al., 2013). Thus, cellulolytic bacteria are classified as alkaliphilic or acidophilic and thermophilic or psychrophilic. They have documented to often produced stable enzymes under harsh conditions for cellulose bioconversion process. Bacterial genera belonging to Cellulomonas, Clostridium, Ruminococcus, Cellulosimicrobium, Thermomonospora, Erwinia, Streptomyces, Bacteriodes, Fibrobacter, Microbispora, Acetovibrio, Paenibacillus and many more have been reported to produce cellulases when cultured aerobically or anaerobically in enzyme production media (Lo et al., 2009; Wilson, 2011).

The increasing demand for cellulases in various industrial process necessitates extension in both qualitative and quantitative improvement in microbial strains producing the enzymes. Overproduction of enzymes requires strain improvement since the yield from wild strains are usually too low such that the industrial demand could not met. Strain improvement in many experimental trials is usually achieved by extensive application mutagens such as Ultra violet radiation, $\mathrm{N}$-methyl- $\mathrm{N}^{\prime}$-nitro-N-nitroso guanidine (NTG), Ethyl Methyl Sulphonate (EMS), Ethidium bromide and nitrous acid resulting in mutation and selection of improved clones (Olaniyi et al., 2014; Sadhu et al., 2014). In many occasions, the effect of these mutagens may be very lethal but sometimes, exposed organisms may develop better adaptation to harsh environment with improved biocatalytic efficiency (Femi-Ola, 2008; Sadhu et al., 2014).

Catabolite repression which is a bottleneck to continuous production of relevant industrial enzymes informed the current study and research efforts are now targeting catabolite insensitive strains. The microbial secretion of extracellular enzymes is regulated by induction and repression mechanism. The rate of cellulose hydrolysis mediated by cellulase has been reported to be impeded by the products generated by hydrolysis and fermentation especially when the two processes are carried out simultaneously (Lynd et al., 2002; Olaniyi et al., 2014). The presence of high content of readily available metabolized carbohydrate source and/or end product of sugar fermentation account for the repression of enzyme in most organisms and increased cost of enzyme production (Kayikc and Nielsen, 2015; Kim et al., 2019). It is hypothesized that catabolite insensitive mutants would bypass cellulase repression and permit high cellulase yield via direct bacterial hydrolysis and fermentation.

Bacterial identity was authenticated using conventional methods. Bacillus subtilis was exposed to different concentrations of EMS and emerged mutants (clones) were screened for cellulase production. Afterwards, wild type and the mutants were cultured enzyme basal media supplemented with different glucose concentrations. Mutants with higher enzyme activity in the presence of repressing sugar were considered as catabolite insensitive mutants. The mutagenesis of wild type $B$. subtilis by EMS led to the development of improved catabolite insensitive mutants.

\section{Materials And Methodology}

\section{Collection of isolates}


Bacillus subtilis CWB isolated from cassava waste water and previously confirmed to have xylanolytic activity capability was obtained from culture bank of the Department of Microbiology, FUTA for this study. The identity of the isolate was authenticated by sub-culturing on fresh nutrient agar and subjected to some biochemical tests. The outcome of which was compared with Bergey's Manual of Determinative Bacteria.

\section{Mutagenesis of Bacillus subtilis}

The isolate was mutagenized following the method of Olaniyi et al. (2014). Bacillus subtilis cultivated in nutrient broth for 24 hours was cold centrifuged at $4^{\circ} \mathrm{C}, 4000 \mathrm{rpm}$ for $15 \mathrm{mins}$ and the supernatant was discarded. The cell debris was severally washed with normal saline, varied concentrations of Ethyl Methyl Sulphonate (EMS) $20 \mu \mathrm{l}, 40 \mu \mathrm{l}, 60 \mu \mathrm{l}$ and $80 \mu \mathrm{l}$ was added respectively and incubated at room temperature for $20 \mathrm{mins}$. The mutagenized cells were washed with normal saline and thereafter diluted with Minimal Salt Medium ( $1 \mathrm{~g} \mathrm{CMC}, 0.1 \mathrm{~g}$ yeast extract, $0.2 \mathrm{~g} \mathrm{NaNO}, 0.05 \mathrm{KCl}, 1.4 \mathrm{~g} \mathrm{KH} 2 \mathrm{PO} 4,0.06 \mathrm{~g} \mathrm{MgSO} 4.7 \mathrm{H} 2 \mathrm{O}, 0.1 \mathrm{~g}$ Peptone) in a ratio 2:10 and incubated for 24 hours. The diluted mutagenized cells were cultivated in nutrient agar and incubated for 24 hours at $37^{\circ} \mathrm{C}$ for individual mutants to emerge. Each emerged colony on the plate was considered to be a mutant. Each mutant encoded with a name is inoculated into a $5 \mathrm{ml}$ nutrient broth.

\section{Primary screening of mutagenized cells for cellulase production}

$50 \mu \mathrm{l}$ of broth culture of the mutant and wild type was inoculated in $5 \mathrm{ml}$ MSM into respective test tubes, incubated at $37^{\circ} \mathrm{C}$ for 24 hours and then centrifuged at 4000 rpm for $15 \mathrm{mins} .50 \mu$ l of serially diluted supernatant from the dilution factor $10^{5}$ was introduced into wells bored in a carboxyl-methyl-cellulose (CMC)-nutrient agar plate and incubated at $37^{\circ} \mathrm{C}$ for $18-24$ hours. The plates were flooded with $1 \%$ Congo red, allowed to stand for 15 mins at room temperature and afterward counterstained with $0.1 \mathrm{M} \mathrm{NaCl}$. Clear zones that appeared around wells indicates $\mathrm{CMC}$ hydrolysis. Clear zone around wells was measured in centimeter ( $\mathrm{mm}$ ) (Olaniyi et al., 2014).

\section{Secondary screening of mutagenized cells for cellulase production}

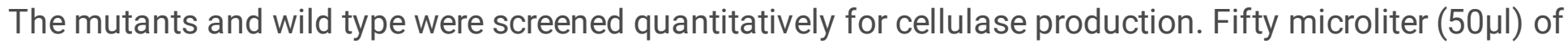
mutants and wild type were inoculated into $3 \mathrm{ml}$ of sterilized cellulase production medium consisting of $0.02 \mathrm{~g}$ peptone, $0.02 \mathrm{~g}$ yeast extract, $0.02 \mathrm{~g} \mathrm{NaNO}_{3}, 0.025 \mathrm{~g} \mathrm{~K}_{2} \mathrm{HPO}_{4}, 0.005 \mathrm{~g} \mathrm{MgSO}_{4}, 0.005 \mathrm{~g} \mathrm{CaCl}_{2}, 0.001 \mathrm{~g}$ $\mathrm{FeSO}_{4} \cdot 7 \mathrm{H}_{2} \mathrm{O}$ and $1 \mathrm{~g}(\mathrm{CMC})$ dissolved in $100 \mathrm{ml}$ of sterile distilled water and incubated at $37^{\circ} \mathrm{C}$ for 24 hours. The medium was cold centrifuged at $6000 \mathrm{rpm}$ to obtain supernatant (crude enzyme) (Femi-Ola, 2008).

\section{Enzyme assay}

Five hundred microliter $(500 \mu \mathrm{l})$ crude enzyme was pipetted in a test tube containing $500 \mu \mathrm{l} \mathrm{CMC} \mathrm{prepared}$ in $50 \mathrm{mM}$ phosphate buffer $\left(\mathrm{pH}\right.$ 6.7). The mixture in test tubes were incubated in a water bath at $45^{\circ} \mathrm{C}$ for 
15 mins and the reaction was terminated by adding $1 \mathrm{ml}$ of DNSA and then boiled at $100^{\circ} \mathrm{C}$ for 10 mins for colour development. One milliliter $(1 \mathrm{ml})$ of distilled water was added to the test tube to bring it up to $2 \mathrm{ml}$ and then read at $540 \mathrm{~nm}$ using spectrophotometer (Waeonukul et al., 2009).

\section{Protein determination}

The protein content in cellulase production medium was determined as described by Lowry et al. (1951) using Bovine Serum Albumin (BSA) as a standard.

\section{Catabolite insensitive mutants}

All the mutants and wild type of $B$. subtilis were subsequently cultured in the enzyme production media supplemented with different concentrations of glucose $(0.2 \mathrm{~g}, 0.5 \mathrm{~g} 1.0 \mathrm{~g}$ and $1.5 \mathrm{~g} \mathrm{w} / \mathrm{v}$ glucose) serving as energy source. Enzyme production and assay were performed as previously mentioned. Mutants that exhibited appreciable enzyme activity were considered as catabolite insensitive mutants (Olaniyi et al., 2014; Kim et al., 2019).

\section{Results}

Table 1 reveals the biochemical characterization of the isolate leading to its authentication. The isolate was positive to catalase, Gram's reaction, nitrate reduction, triple sugar iron, citrate, gelatin hydrolysis and negative to indole and oxidase. The isolate was tentatively identified as $B$. subtilis.

Table 2 shows the qualitative screening of cells mutagenized with EMS and wild type $B$. subtilis for cellulase production on $\mathrm{CMC}$-agar medium. The mutants showed different hydrolysis zones on $\mathrm{CMC}$-agar media indicating varied cellulase activities, the zone ranged from 2.8 to $6.5 \mathrm{~mm}$. The highest zone of hydrolysis of $6.5 \mathrm{~mm}$ was obtained from the mutant designated M01, while mutant M08 showed the least zone of $2.8 \mathrm{~mm}$. Approximately $57 \%$ of the mutants (MS04, MS03, MSO2 and MS01) had higher zone of hydrolysis than the value obtained from the wild type. The mutants emerged from $40 \mu \mathrm{EMS}$ treatment and wild type exhibited varied zones of hydrolysis on CMC-agar media. Mutant with code MSS03 was the only 
Table 1

Morphological and biochemical identification of Bacillus subtilis

\begin{tabular}{|ll|}
\hline Biochemical Tests & Results \\
\hline Cell shape & Rods \\
\hline Motility & Positive \\
\hline Catalase & Motile \\
\hline Indole & Positive \\
\hline Triple sugar iron & Negative \\
\hline Citrate & Positive \\
\hline Gelatin hydrolysis & Positive \\
\hline Oxidase & Positive \\
\hline Nitrate reduction & Negative \\
\hline
\end{tabular}

Table 2

Hydrolysis zones on CMC-agar media by mutants of wild type B. subtilis developed from different concentrations of EMS

\begin{tabular}{|llllllll|}
\hline Mutant code & $\mathbf{2 0} \boldsymbol{\mu l}$ & Mutant code & $\mathbf{4 0} \boldsymbol{\mu l}$ & Mutant code & $\mathbf{6 0} \boldsymbol{\mu l}$ & Mutant code & $\mathbf{8 0} \boldsymbol{\mu l}$ \\
\hline MS01 & 4.2 & MSS01 & 3.0 & MSSS01 & 3.6 & MSST01 & 3.6 \\
\hline MS02 & 4.0 & MSS02 & 3.1 & MSSS02 & 3.9 & MSST02 & 3.8 \\
\hline MS03 & 3.8 & MSS03 & 5.1 & MSSS03 & 5.5 & MSST03 & 3.4 \\
\hline MS04 & 5.8 & MSS04 & 3.6 & MSSS04 & 5.7 & MSST04 & 5.5 \\
\hline MS05 & 3.1 & MSS05 & 3.2 & MSSS05 & 3.8 & MSST05 & 3.3 \\
\hline MS06 & 3.6 & MSS06 & 3.0 & MSSS06 & 3.8 & MSST06 & 2.6 \\
\hline MS07 & 3.5 & MSS07 & 3.6 & MSSS07 & 4.0 & MSST07 & 2.8 \\
\hline Wild Type & 3.6 & Wild Type & 3.6 & Wild Type & 3.6 & Wild Type & 3.6 \\
\hline
\end{tabular}


mutant out of the entire mutants screened that had higher value than the wild type. Mutant strain with a code MSSS04 from $60 \mu \mathrm{l}$ EMS treatment showed the highest zone of hydrolysis of $5.7 \mathrm{~mm}$ on CMC-agar, while MSSS01, MSSS02, MSSS03, MSSS05, MSSS06 and MSSS07 showed zones of hydrolysis of 3.6

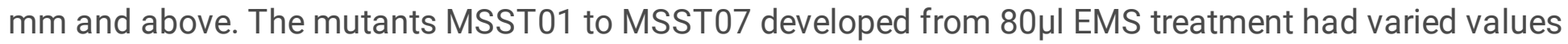
of zone of clearance. The highest zone of hydrolysis of $5.5 \mathrm{~mm}$ was recorded from mutant MSST04, followed by mutant MSST01 $(3.8 \mathrm{~mm})$, MSST02 $(4.0 \mathrm{~mm})$, while the least value of $2.6 \mathrm{~mm}$ was obtained from mutant MSST06. The wild type had higher zone of hydrolysis than MSST03, MSST05, MSST06 and MSST07.

The quantitative screening of cells mutagenized with EMS and wild type $B$. subtilis for cellulase production in liquid fermentation is presented in Fig. 1 to 4 . Quantitatively, all the mutants developed from $20 \mu \mathrm{l} \mathrm{EMS} \mathrm{treatment} \mathrm{exhibited} \mathrm{specific} \mathrm{xylanase} \mathrm{activity} \mathrm{ranging} \mathrm{from} 3.4242 \mu \mathrm{mol} / \mathrm{min} / \mathrm{mg}$ by MS01 to $16.50 \mu \mathrm{mol} / \mathrm{min} / \mathrm{mg}$ by MS05 (Fig. 1). However, wild type had specific activity of 13.67 $\mu \mathrm{mol} / \mathrm{min} / \mathrm{mg}$, which was higher than the values exhibited by approximately $86 \%$ of the mutants (MS01, MS02, MS03, MS04, MS06 \& MS017). A total of seven mutant strains developed from $40 \mu \mathrm{l}$ EMS treatment produced varied specific xylanase activities with the highest specific activity of 15.97 $\mu \mathrm{mol} / \mathrm{min} / \mathrm{mg}$ exhibited by MSS07, while the least value of $5.38 \mu \mathrm{mol} / \mathrm{min} / \mathrm{mg}$ was produced by MSS05 (Fig. 2). Approximately $86 \%$ of the mutants (MSS01, MSS02, MSS03, MSS04, MSS05 \& MSS06) had lesser specific activity than the wild type. Two out (MSSS01 \& MSSS02) of the seven mutants developed from $60 \mu \mathrm{l}$ EMS had their cellulase production improved when compared with the wild type, while all the mutants generated from $80 \mu \mathrm{l}$ EMS had lower specific activities than the wild type (Figs. $3 \& 4$ ).

Figure 5 reveals the effect of $0.2 \%(\mathrm{w} / \mathrm{v})$ glucose supplementation on mutagenized and wild type $B$. subtilis for cellulase production. The mutant strains showed lower specific cellulase activity when compared with wild type. In a medium supplemented with $0.5 \%(\mathrm{w} / \mathrm{v})$ glucose, mutants MSSS02 \& MSSS05 had higher specific cellulase activity than the wild type, while there was repression of specific cellulase activity in others (Figure 6). Similarly, mutants MSSS02 \& MSSS05 cultured in a medium supplemented with $1 \%(\mathrm{w} / \mathrm{v})$ glucose had higher specific cellulase activity than the wild type, while the rest of the mutants had their cellulase activities repressed (Figure 7). The supplementation of enzyme production medium with $1.5 \%(\mathrm{w} / \mathrm{v})$ glucose caused repression of cellulase production in all the mutants except for MSSS05 which had approximately $34 \%$ higher than the wild type (Figure 8).

\section{Discussion}

Improvement in microbial strains is an integral part of process for improved bio-products formation and it often achieved majorly by mutation, a primary source of genetic alteration in parent or wild type. Alteration of microbial genetic makeup can be induced by exposing the organism of interest to a chemical mutagen such as Ethyl methyl sulphonate (EMS) or physical mutagen such as ultraviolet radiation. Mutagenized microbial strains with acquired improved and desirable properties are used 
intensively in many industrial processes with a view to reduce cost of production. Thus, recent research efforts are directed towards improving microbial strains via induced mutagenesis for enhanced bioproducts formation (Olaniyi et al., 2014; Adeleke et al., 2017).

In this study, exposure of wild type $B$. subtilis to different concentrations of EMS led to an emergence of mutants with varied cellulase activities. In terms of enzyme yield, very few of the mutants had better performance than the wild type. Strains of $B$. subtilis had been improved for industrial enzymes production by the use of chemical mutagens such as EMS, N-methyl- $\mathrm{N}^{\prime}$-nitro-N-nitroso guanidine and Ethidium bromide (Femi-Ola, 2008; Sangkharak et al., 2012; Olaniyi et al., 2015; Park et al., 2017). FemiOla (2008) isolated $B$. subtilis from termite and afterward mutagenized it with EMS, and a certain number of the mutants had their cellulase production capacities improved. A mutant from wild type $B$. subtilis represented by P11 developed from EMS treatment had higher endoglucanase production than the wild type (Park et al., 2017). A putative mutant, C1M 26 from wild type Bacillus sp. strain C1 after mutagenized with N-methyl- $\mathrm{N}^{\prime}$-nitro-N-nitroso guanidine (NTG) yielded more cellulase in comparison with a wild type (Sadhu et al, 2014). Similarly, a mutant emerged from NTG treatment yielded higher cellulase than the wild type Cellulomonas sp. TSU-03 (Sangkharak et al., 2012). Cellulase genes within the improved mutants were suggested to have been affected positively by EMS. However, how cellulase production was triggered in these mutants is yet to be unraveled. We hypothesized that regulatory genes or stability of the nucleotide sequence of mRNA might have been affected by EMS resulting in better cellulase bio-synthesis (Sadhu et al., 2014). Narasimha et al. (2012) and Olaniyi et al. (2014) however attributed improved cellulase bio-synthesis in these few mutants to ease of reconstitution of damaged genes with desired properties. Factors such as damaged DNA sequence and differences in the ability of the mutants to repair damaged genes could account for the variations in cellulase production (Narasimha et al., 2012; Olaniyi et al., 2014).

Cellulase production was repressed in many of the mutants cultured in media supplemented with different concentrations of glucose with few exceptions. Repression of cellulase production in the wild type and mutant strain is expected because glucose, a monosaccharide is already available in enzyme production media and hence there is no need for the secretion of cellulose-degrading enzymes. The preferential utilization of glucose in the presence of other carbohydrates is refers to as catabolite repression and it is regulated by cyclic AMP (Brock and Madigan, 1991). Cyclic AMP interact with allosteric protein known as catabolite gene activation protein (CAP) or cyclic AMP receptor protein (CRP) to form a complex that facilitate prompt binding of RNA polymerase to the promoter site of catabolite sensitive operon which eventually result in the alleviation of the repression state. The secretion of other enzymes capable of utilizing other $\mathrm{CHO}$ sources through CRP is impossible as long as the glucose is readily available because its presence lowers the concentration of AMP (Bakare et al., 2005; Olaniyi et al., 2014). This relate to the repression of cellulase production in mutants of $B$. subtilis in current study since they were cultivated in media supplemented with different concentrations of glucose. Repression of cellulase production had been well researched and documented (Kotchoni et al., 2003; Bakare et al., 2005; Zang and Lynd, 2005; Olaniyi et al., 2014). The few mutants with improved cellulase production could be regarded as catabolite insensitive mutants since their cellulase production potentials in the presence of 
high glucose was not impaired. The genes that regulate catabolite repression in these catabolite insensitive mutants might have lost their regulatory functions thereby allowing uninterrupted production of cellulase in the presence of repressing glucose (Olaniyi et al., 2014).

The outcome of this investigation indicates that few of the EMS treated mutants produced higher cellulase than the wild type $B$. subtilis. In a bid to overcome the hurdle of catabolite repression, mutants MSSS02 and MSSS05 generated from $60 \mu$ EMS was believed to successfully utilized CMC in the presence of relatively high D-glucose concentration to produce substantial amount of cellulase. Thus, these two mutants (MSSS02 and MSSS05) catabolite insensitive mutants. Conclusively, chemical mutagenesis by EMS caused improvement of cellulase production in few of the mutants by mutation of regulatory genes governing the operation of cyclic AMP or by some mechanisms yet to be known. Therefore, genetic studies on catabolite insensitive mutants might be necessary to reveal altered DNA sequence with improved properties.

\section{Declarations}

\section{Acknowledgements}

Author acknowledges the technical supports from the Department of Biochemistry, FUTA. This research did not receive any financial support from any funding agency.

\section{Ethics approval and consent to participate}

Not applicable

\section{Consent for publication}

The author consented for publication in the ABM Express. The current manuscript has been submitted exclusively to this journal and it is not simultaneous considered by another journal. The author declares that no similar work has been submitted to or published by another journal.

\section{Availability of data and materials}

Not applicable

\section{Competing interest}

It is single-authored manuscript and no conflicts of interest is declared by the author regarding this study.

\section{Funding}

This research did not receive any financial support from any funding agency.

\section{Author contributions}


Olaniyi, Oladipo Oladipo contributed reagents and materials, carried out the experiment, analyzed and interpreted the data, conceived and designed the experiments and wrote the paper.

\section{References}

Abdelnasser, S. S. I.; Ahmed, I. E. Isolation and identification of new cellulases producing thermophilic bacteria from an Egyptian hot spring and some properties of the crude enzyme. Australian j. basic appl. sci., v. 1, p. $4738,2007$.

Adeleke, B. S.; Akinyele, B. J.; Olaniyi, O.O.; Agboola, Y. A. Effect of fermentation on chemical composition of cassava peels. Asian j. plant sci. res., v. 7, no. 1, p. 31-37, 2017.

Bakare, M. K.; Adewale, I. O.; Ajayi, A. O.; Okoh, A. I.; Shonukan, O. O. Regulatory mutations affecting the synthesis of cellulase in Pseudomonas fluorescens. Afri. J. biotechnol., v. 4, no. 8, p. 838-843, 2005.

Bras, J. L. A.; Cartmell, A.; Carvalho, A. L. M. et al. "Structural insights into a unique cellulase fold and mechanism of cellulose hydrolysis," Proceedings of the National Academy of Sciences of the United States of America, v.108, no.13, p. 5237-5242, 2011. DOI: 10.1073/pnas.1015006108

Brock, T. D.; Madigan, M. T. Biology of microorganisms. $6^{\text {th }}$ edition. Prentice Hall International Inc. Englewood Cliffs, U.S.A. p. 835, 1991.

Cherry, J. R.; Fidantsef, A. L. Directed evolution of industrial enzymes: an update. Curr. opinion biotechnol.,. v. 14, no. 1, 438-443, 2003. DOI: 10.1016/s0958-1669(03)00099-5.

Deswal, D.; Khasa, Y. P.; Kuhad, R. C. "Optimization of cellulase production by a brown rot fungus Fomitopsis sp. RCK2010 under solid state fermentation," Biores. technol., v. 102, no.10, p. 6065-6072, 2011. DOI: 10.1016/j.biortech.2011.03.032

Doi, R. H. Cellulase of mesophilic microbes: cellulosome and non-cellulosome producers. Ann. NY. Acad. sci., v. 1125, p. 267-279, 2008. DOI: 10.1196/annals.1419.002

Femi-Ola, T. O. Regulatory mutations affecting the synthesis of cellulase in Bacillus pumilus. J. pure appl. Microbiol., v. 2, no. 1, p. 181-186, 2008.

Islam, F.; Roy, N. Screening, purification and characterization of cellulase from cellulase from cellulase producing bacteria in molasses. BMC Research Notes, v. 11, no. 445, p. 2-6, 2018.

DOl.org/10.1186/s13104-018-3558-4.

Kayikci, Ö.; Nielsen, J. Glucose repression in Saccharomyces cerevisiae. FEMS yeast res., v. 15, no. 6, p. 16, 2015. DOI: 10.1093/femsyr/fov068.

Kim, S.; Kwon, D-H.; Park, J-B.; Ha, S-J. Alleviation of catabolite repression in Kluyveromyces marxianus: the thermotolerant SBK1 mutant simultaneously coferments glucose and xylose. Biotechnol. biofuels, v. 
12, no. 90, p. 1-9, 2019. https://doi.org/10.1186/s13068-019-1431-x

Kotchoni, O. S.; Shonukan, O. O.; Gachomo, W. E. "Bacillus pumilus BpCRI 6, a promising candidate for cellulase production under conditions of catabolite repression," Afri. j. Biotechnol., vol.2, no.6, p.140-146, 2003.

Lo, Y.C.; Saratale, G.D.; Chen, W. M.; Bai, M. D.; Chang, J. S. "Isolation of cellulose-hydrolytic bacteria and applications of the cellulolytic enzymes for cellulosic biohydrogen production," Enzyme and Microbial Technology, v. 44, no. 6-7, p.417-425, 2009. DOl.org/10.1016/j.enzmictec.2009.03.002

Lowry, O. H.; Rosebrough, J. N.; Farr, L. A.; Randali, J. R. Protein measurement with the Folin-Phenol reagents. J. biol. Chem., v. 193, no.1, p. 265-275. 1951.

Lynd, L. R.; Weimer, P. J.; Vanzyl, W. H. Pretorius IS. Microbial cellulose utilization: Fundamentals and Biotechnology. Microbiology and Biology Review, v. 66, no. 5, p. 506-577, 2002. DOI:

10.1128/mmbr.66.3.506-577.2002.

Marjamaa, K.; Toth, K.; Bromann, P. A.; Szakacs, G.; Kruus, K. “Novel Penicillium cellulases for total hydrolysis of lignocellulosic," Enzyme and Microbial Technology, v. 52, no. 6-7, p. 358-369, 2013. DOI.org/10.1016/j.enzmictec.2013.03.003.

Narasimha, G.; Radha, S.; Himakiran, B. I. R.; Sridevi, I. A.; Prasad, N. B. L. Development of mutant fungal strains of Aspergillus niger for enhanced production of acid protease in submerged and solid-state fermentation. European Journal of Experimental Biology, v. 2, no. 5, p. 1517-1528, 2012.

Olaniyi, O. O.; Akinyele, B. J.; Ibitoye, O. F. Mutagenesis of Klebsiella edwardsii for mannanase synthesis. Innovative Romanian Food Biotechnology, v. 15, no.1, p. 40-45, 2014.

Olaniyi, O. O.; Ibitoye, O. F.; Familoni, T. V.; Bankefa, E. O. UV Mutagenesis of Aspergillus flavus for enhanced mannanase synthesis and catabolite activation studies. Res. j. microbiol., v. 10, no. 11, p. 542550, 2015. DOI: 10.3923/jm.2015.542.55.

Park, E.; Lee, S. S.; Kim, B.; Cho, B.; Cho, S.; Cho, K. J.; Ha, J. K.; Seo, K. Isolation of endo-1,4-ß-D-glucanase producing Bacillus subtilis sp. from fermented foods and enhanced enzyme production by developing the mutant strain. Indian j. anim. res., v. 51, no. 4, p. 785-790, 2017. DOI: 10.18805/ijar.v0iOF.7253.

Perez, J.; Munoz-Dorado, J.; de la Rubia, T.; Martinez, J. Biodegradation and biological treatments of cellulose, hemicellulose and lignin: an overview. Int. j. Microbiol., v. 5, no. 1, p. 53-63, 2002. DOI: 10.1007/s10123-002-0062-3.

Romeo, T. Bacterial bioflms. Berlin: Springer. p. 258-263, 2008. ISBN 978-3-540-75418-3

Sadhu, S.; Ghosh, P. K.; Aditya, G.; Maiti, T. K. Optimization and strain improvement by mutation for enhanced cellulase production By Bacillus sp. (MTCC10046) isolated from cow dung. Journal of King 
Saud University-Science, v. 26, no. 1, p. 323-332, 2014. DOI.org/10.1016/j.jksus.2014.06.001.

Saha, P.; Chakrabarti, T. Emticicia oligotrophicagen. nov., sp. nov., a new member of the family 'flexibacteraceae' Phylum Bacteroidetes. International Journal of Systemic and Evolutionary Microbiology. v. 56, no. 1, p. 991-995, 2006.

Sangkharak, K.; Vangsirikul, P.; Janthachat, S. Strain improvement and optimization for enhanced production of cellulase in Cellulomonas sp. TSU-03. Afri. j. microbiol. Res., v. 6, no. 5, p. 1079-1084, 2012. DOI: 10.5897/AJMR11.1550.

Shanmugapriya, K.; Saravana, P. S.; Krishnapriya, M. M.; Mythili, A.; Joseph, S. Isolation, screening and partial purification of cellulose from cellulose producing bacteria. International Journal of Advances in Biotechnology Research. v. 3, no. 1, p. 509-514, 2012.

Waeonukul, R.; Kyu, K. L.; Sakka, K.; Ratanakhanokchai, K. "Isolation and characterization of a multienzyme complex (cellulosome) of the Paenibacillus curdlanolyticus B-6 grown on Avicel under aerobic conditions," J. Biosci. Bioeng., v.107, no.6, p. 610-614, 2009.

Wilson, D. B. "Microbial diversity of cellulose hydrolysis," Curr. Opinion Microbiol., v. 14, no. 3, p. 259-263, 2011. DOI.org/10.1016/j.mib.2011.04.004.

Zang, Y. P.; Lynd, L. R. Regulation of cellulase synthesis in batch and continuous cultures of Clostridium thermocellum. J. bacterial., p. 99-106, 2005. DOI: 10.1128/JB.187.1.99-106.2005.

\section{Figures}




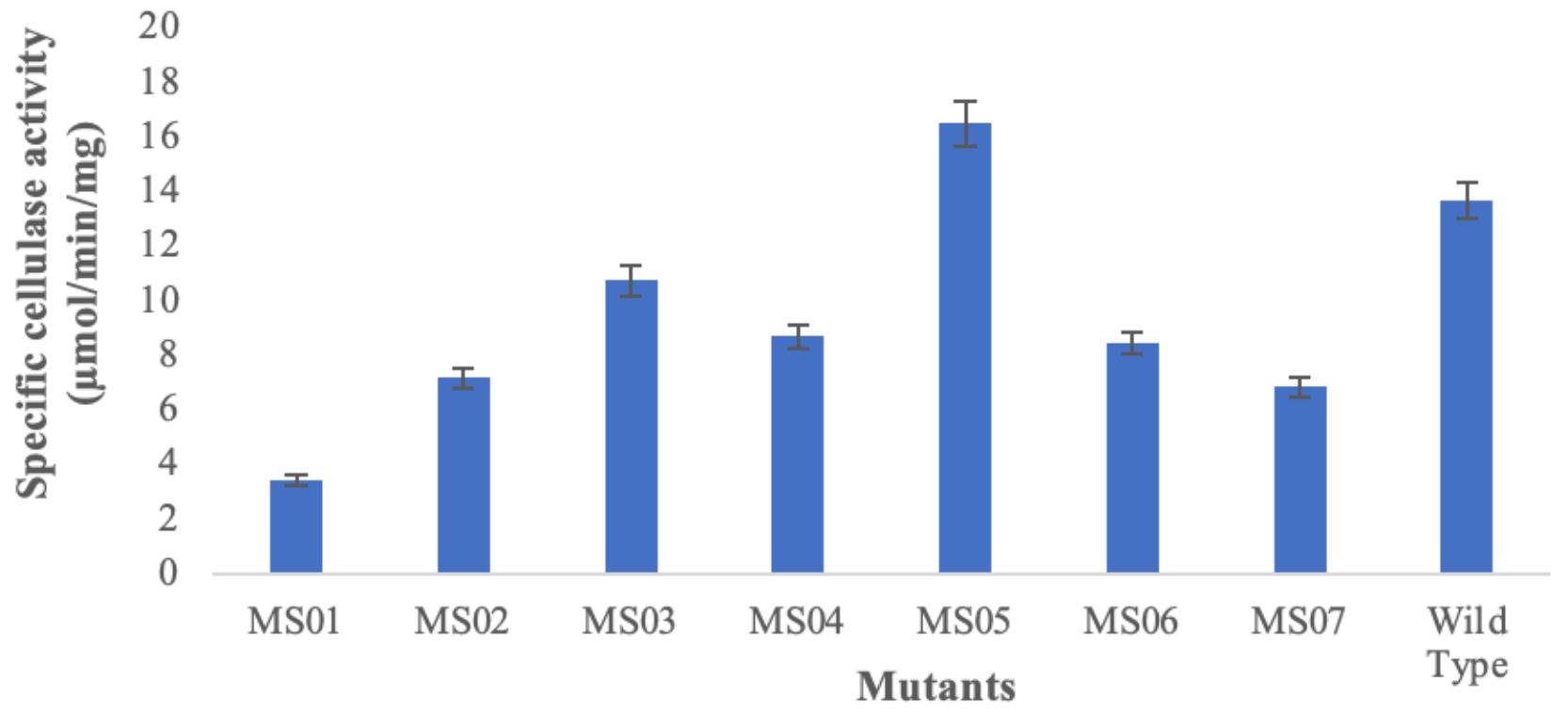

\section{Figure 1}

Cellulase production by mutants developed from $20 \mu \mathrm{EMS}$ in comparison to wild type B. subtilis

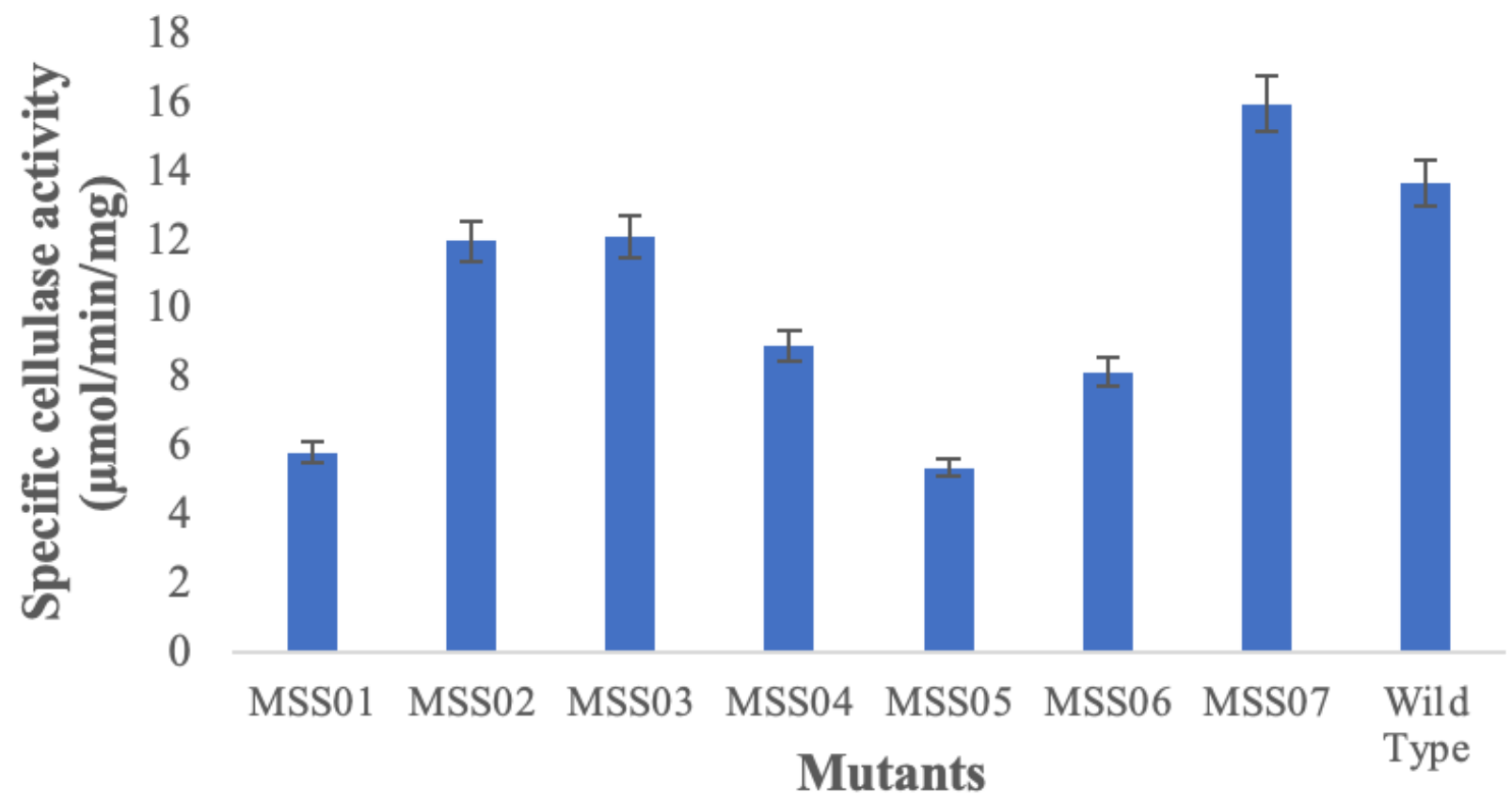

Figure 2

Cellulase production by mutants developed from $40 \mu \mathrm{l}$ EMS in comparison to wild type B. subtilis 


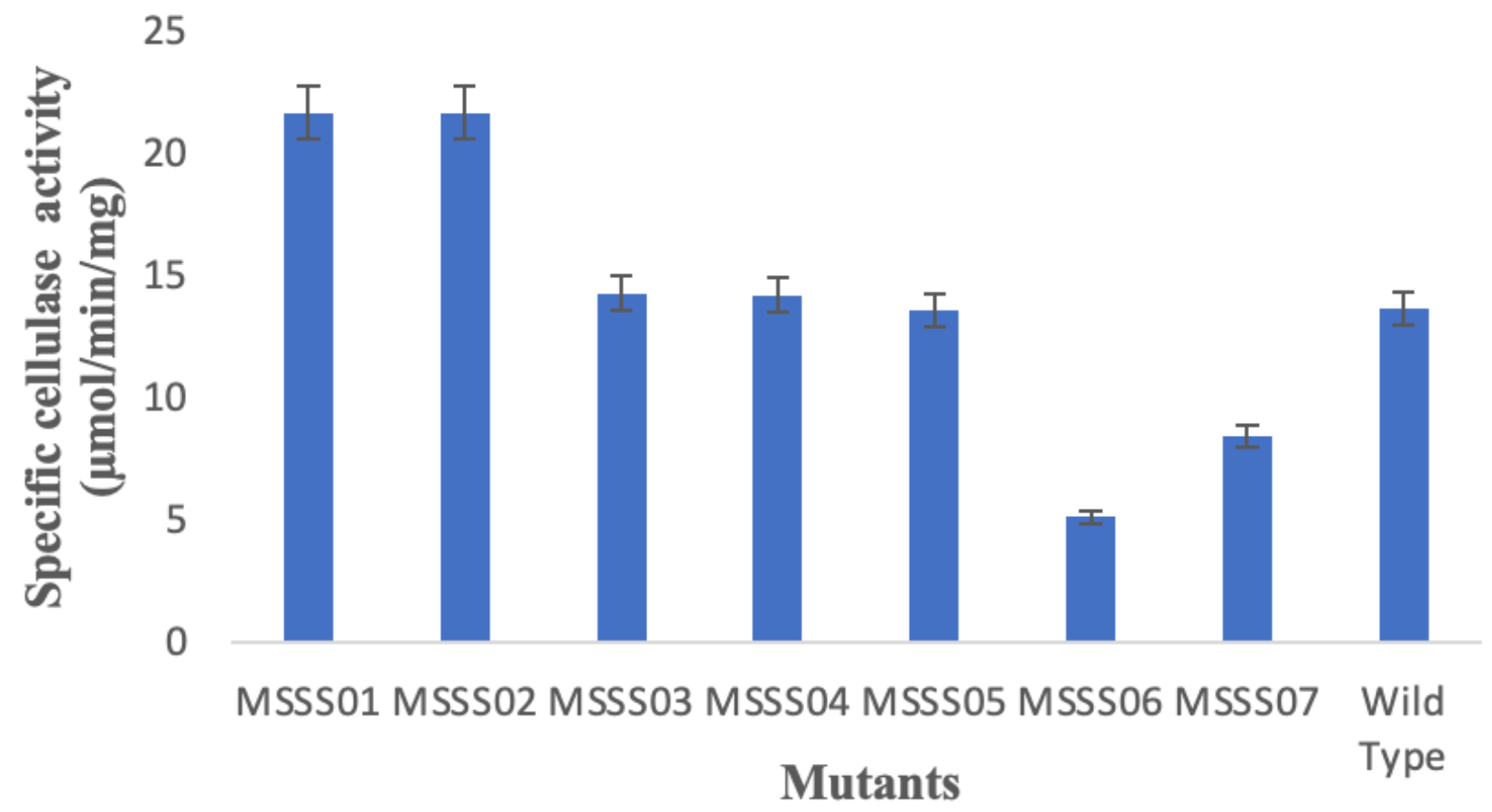

Figure 3

Cellulase production by mutants developed from $60 \mu \mathrm{LMS}$ in comparison to wild type B. subtilis

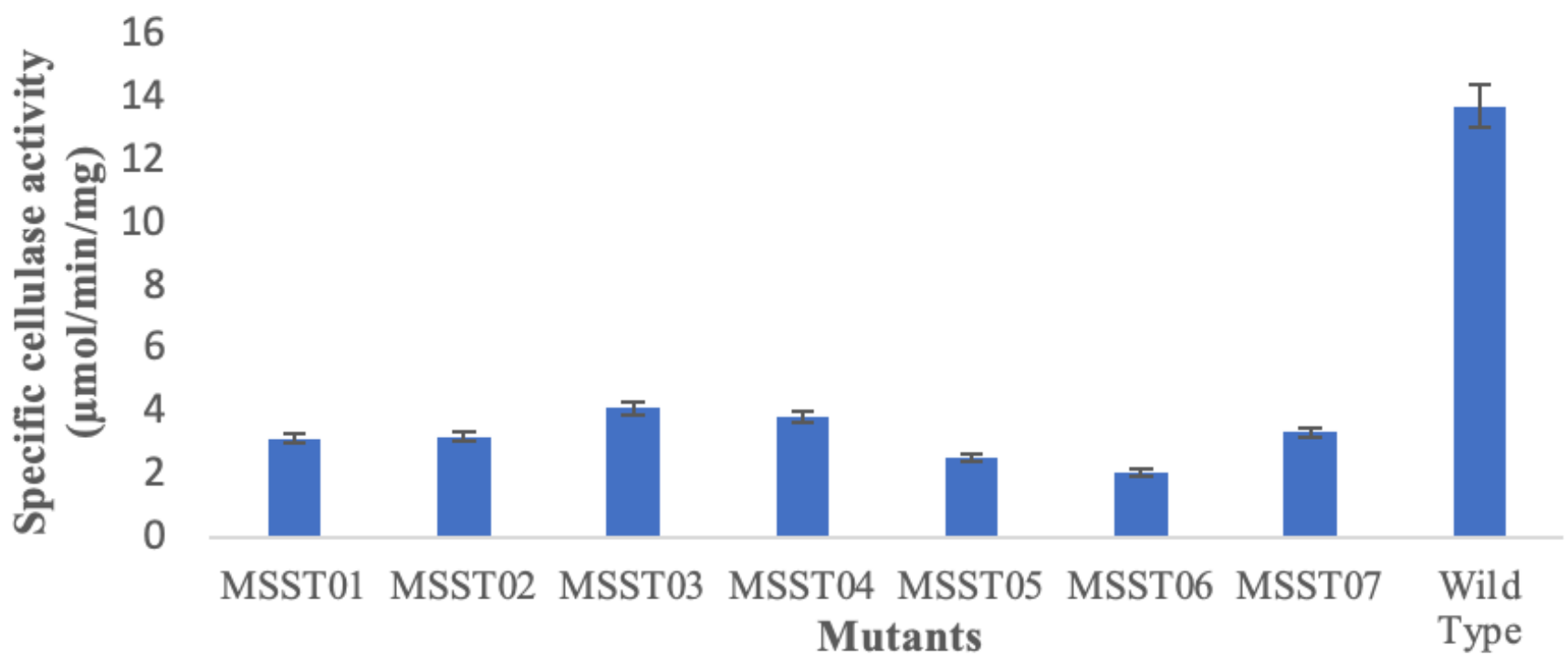

Figure 4

Cellulase production by mutants developed from $80 \mu \mathrm{l}$ EMS in comparison to wild type B. subtilis 


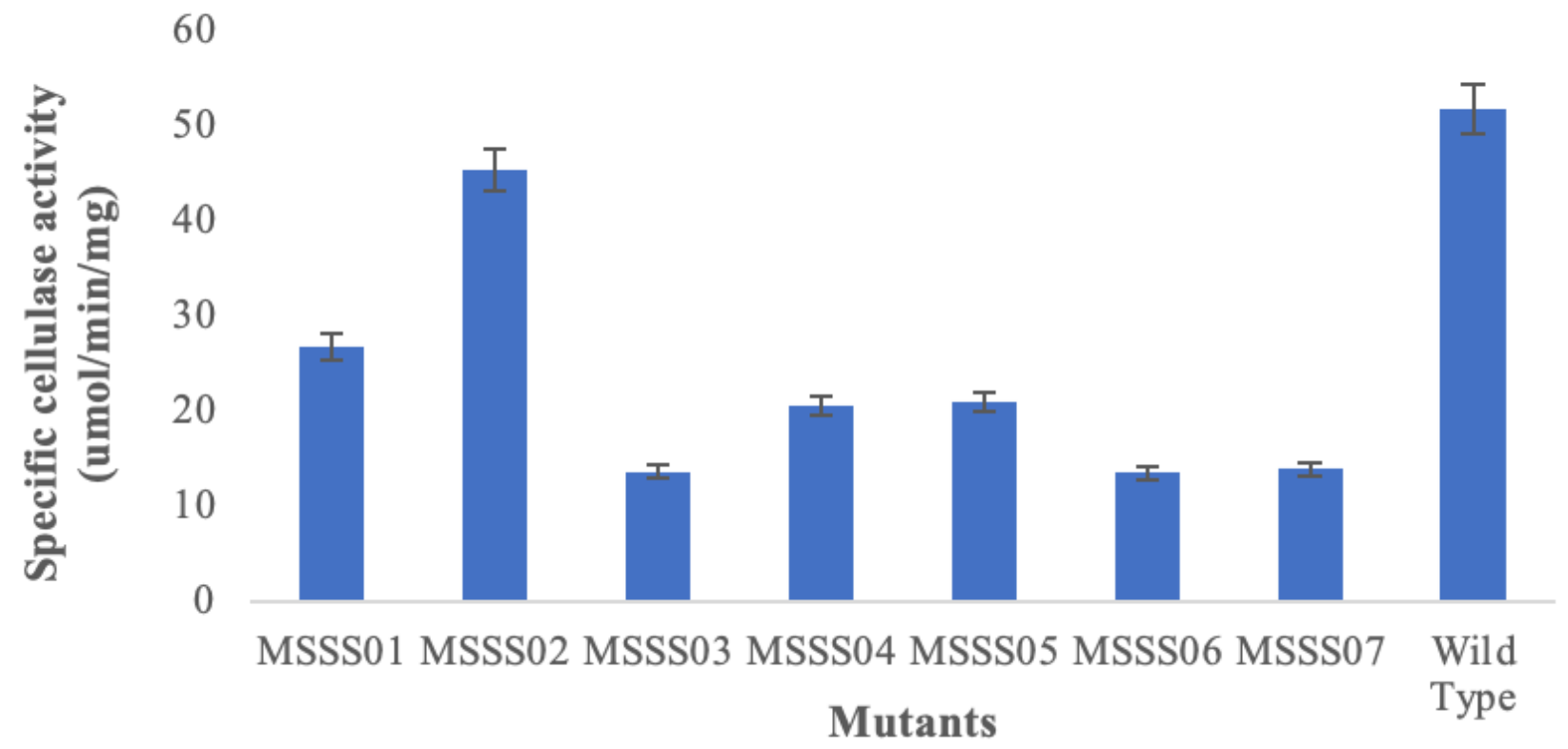

Figure 5

Cellulase production by mutants developed from $60 \mu \mathrm{EMS}$ and wild type B. subtilis cultured in $0.2 \%$ (w/v) D-glucose

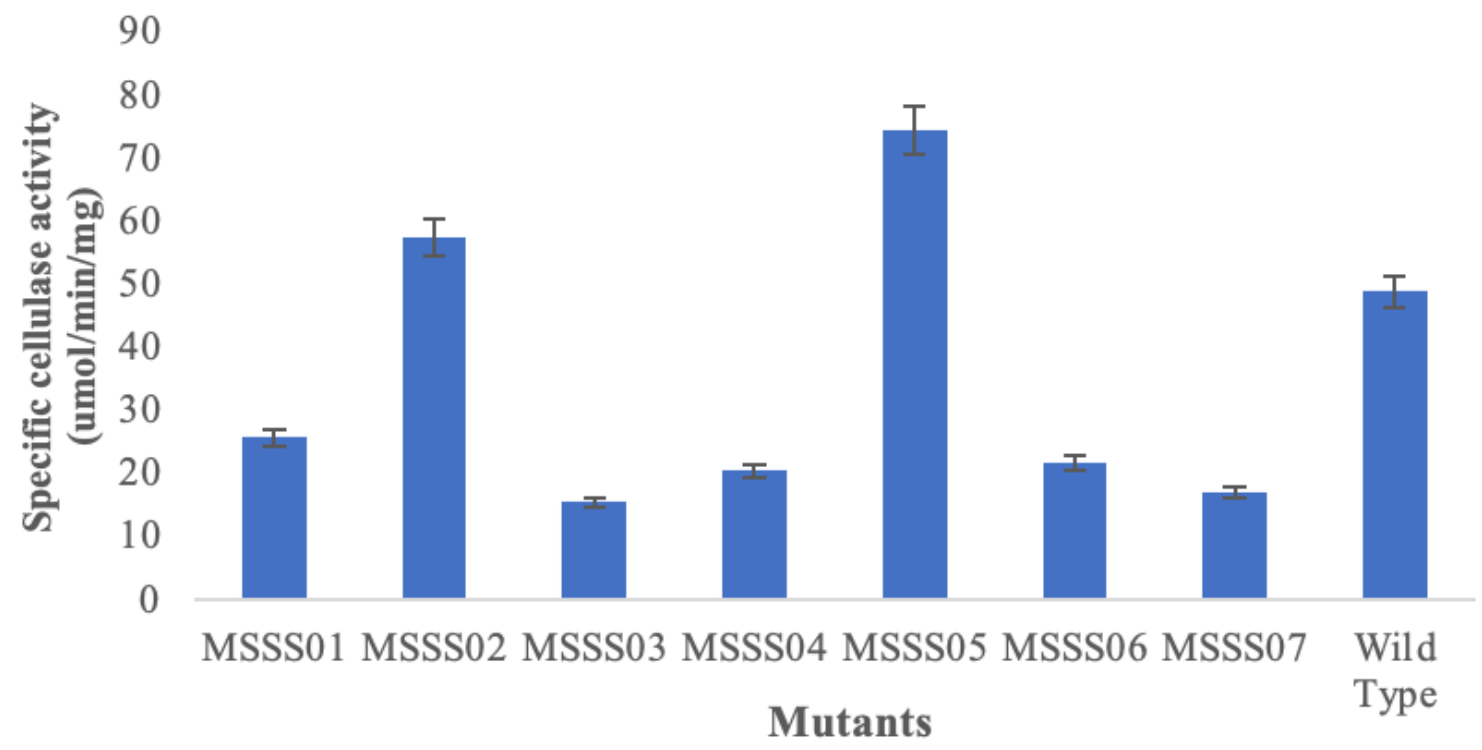

Figure 6

Cellulase production by mutants developed from $60 \mu \mathrm{l}$ EMS and wild type B. subtilis cultured in $0.5 \%$ (w/v) D-glucose 


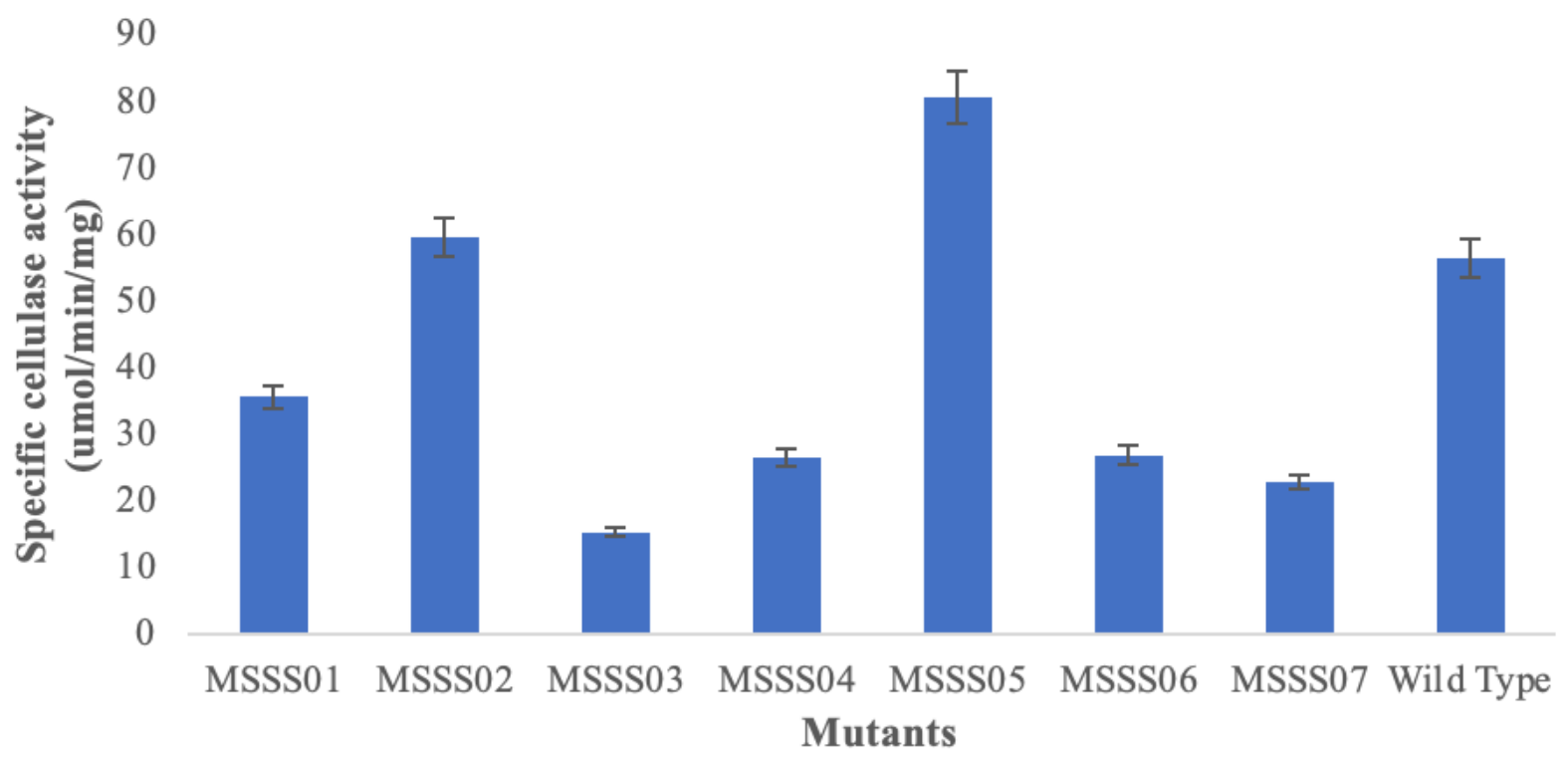

Figure 7

Cellulase production by mutants developed from $60 \mu \mathrm{l}$ EMS and wild type B. subtilis cultured in $1.0 \%$ (w/v) D-glucose

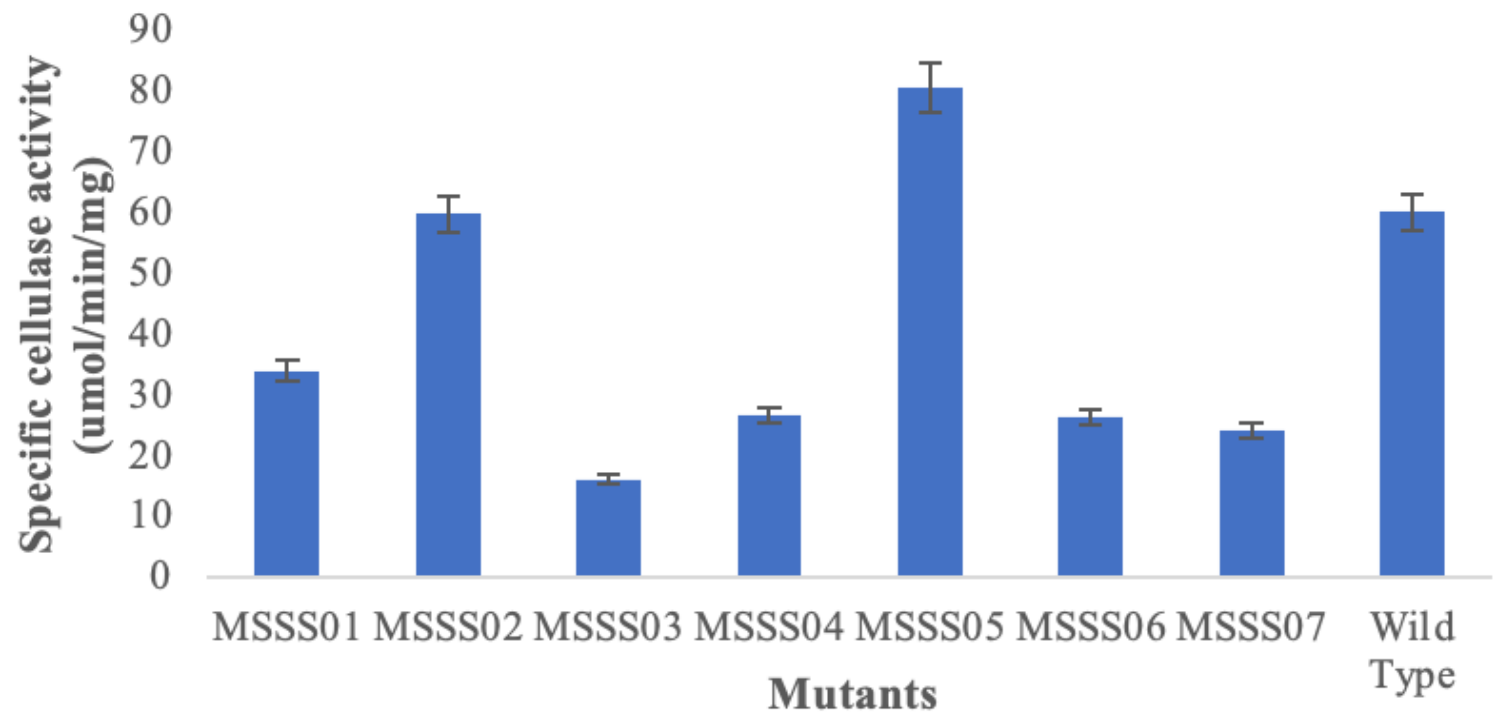

Figure 8 
Cellulase production by mutants developed from $60 \mu \mathrm{l}$ EMS and wild type B. subtilis cultured in $1.5 \%$ (w/v) D-glucose 